\title{
The Genomics Revolution and Development Studies: Science, Poverty and Politics
}

\author{
RONALD J. HERRING
}

Cornell University, New York, USA

\begin{abstract}
The genomics revolution in biology has enabled technologies with unprecedented potential; genetic engineering is changing the terrain of development studies. Societies have reacted with indifference or appreciation to genetically engineered pharmaceuticals, beginning with insulin; yet for food and agriculture, a globally contentious politics and unprecedented policy dilemmas have arisen. Transgenic organisms raise questions of property, ethics and safety unimaginable a generation ago: what can be owned and with what responsibility? Much turns on science: how one conceptualizes evidence, knowledge, uncertainty and risk. Both opponents and proponents of frontier applications in biotechnology have a poverty story to tell, but with divergent implications. The balance in this global debate has perceptibly shifted; a new developmentalist consensus concludes that the world's poor may benefit from genetic engineering: the question is 'under what conditions'? This essay introduces a collection of scholarly treatments that begin with the needs of the poor - for income, nutrition, environmental integrity - and evaluate theory and evidence for contributions from transgenic crops. The new consensus assumes much about biosafety, bioproperty and biopolitics that is contrary to ground realities - the actual capacity of firms and states to monitor and control biotechnology - but raises new questions at the frontiers of development studies.
\end{abstract}

\section{Promethean Science, Pandora's Jug}

The intersection of technological change, human progress, and threats to vulnerable populations is the locus of classic controversies in development studies. Ned Ludd contributed his name to one hostile characterisation of opponents of technical change, but raised the critical developmental question: whatever some notional aggregate cost-benefit ratio indicates, there is a socially charged question of disaggregation: whose benefits and whose costs?

The genomics revolution in biology resonates with previous contestations of technical change, but has raised genuinely new problematics: property claims and 
novel organisms unimaginable a generation ago, with implications for human health, food production, trade regimes and environmental integrity. In medical applications, genetic engineering based on recombinant DNA technologies has brought mostly quiescent or appreciative responses from mass publics. Neither diabetic patients nor their physicians typically resist synthetic human insulin, for example, though it has been produced by genetically engineered organisms since 1978. Transgenics in the pharmaceutical sector have been largely immune to mass mobilisation; as with insulin, life-saving is widely accepted as a legitimate trade-off for uncertainty - or, at a minimum, a political reason to focus mobilisation efforts elsewhere. Yet in agriculture and food systems conflicts are dramatic: field-trial crops are burned, experimental stations are attacked, a remarkable transcontinental caravan of farmers travels from India to Europe to protest the global power of multinationals controlling 'GMOs' (Madsen, 2001). The scope of this global dispute is reflected in titles of recent books: Gene Wars; Pandora's Picnic Basket; Lords of the Harvest; Politics of Precaution; Seeds of Suicide. ${ }^{1}$

Science is the fulcrum on which this contentious politics rests. Science as agnostic method for adjudicating truth claims in applied genomics is overwhelmed by a politicised science constructed either as target or legitimation in strategies of corporations, government agencies, evangelical politicians, social movements and NGOs. Science becomes less method than arena. 'Junk science' is a common epithet hurled at Vandana Shiva - the leading Pandoran - who writes of 'imperialist science'. 'Western science' as derogatory identifies a logic of inquiry that claims for itself no geography (Nanda, 2003: 125-181). It is not, as pro-biotechnology forces often argue, a contest between Science and Luddism. Science does not presume to answer questions in normative theory, nor risk preferences. Moreover, there are scientists deeply troubled by genetically engineered organisms. ${ }^{2}$ There are specifiable 'known unknowns' - horizontal gene flow, allergenicity from novel proteins -and almost certainly 'unknown unknowns' as well.

To say that biotechnology ${ }^{3}$ constitutes 'Promethean' science constitutes a normative stance: there are risks - as with the mythical gift of fire from Prometheus to humans - but also potential for great good achievable in no other way. ${ }^{4}$ In gifting fire, Prometheus understood that it would confer novel powers and comforts, but also new hazards for humans and other species. Opponents of genetic engineering argue that we are dealing not with Promethean promise and calculable risk, but with Pandora's jug, with correspondingly darker connotations. Pandora was in Greek mythology the first woman on earth, given by Zeus to Epimetheus, brother of Prometheus; Pandora and Prometheus were related from the beginning. Pandora came with a sealed jug - or box in some tellings - that was not to be opened. Opening the jug released all evils that afflict the human species. Pandora's lesson is that unanticipated consequences of a characteristic human trait - curiosity - may be catastrophic. Inquisitive behaviour beyond some limits is proscribed; in criticisms of biotechnology, the creation of organisms nature cannot make is equated to 'playing God', with severe precautionary implications. ${ }^{5}$

A global debate reproduces cleavages introduced by Prometheus and Pandora: between camps that believe the genomics revolution to be more like fire - a source of human progress, entailing risks but amenable to control and wise use - and those who believe it to be more like Pandora's jug, set to unleash unimagined evils on our 
species and others: from ecological disaster to bioterrorism. ${ }^{6}$ Divergent claims to knowledge reflect and justify widely varying, socially conditioned distributions of risk aversion and risk acceptance (Douglas and Wildavsky, 1982). Most North Americans consume transgenic foods with little thought of allergenicity; Europeans are more likely to reject the same foods. Zambia and Zimbabwe in 2002 rejected United Nations food aid containing some transgenic maize kernels in the midst of famine, terming the shipment 'poison'? The poison in question is corn that American parents feed their children routinely. It is hard to exaggerate this cognitive chasm.

Genomic fault lines have not followed familiar North-South tectonics. Among the leaders in genetically engineered crops are China and Argentina - and more recently Brazil - along with the US and Canada. Significant opposition has appeared in Europe and some African nations, and in metropolitan Asia. Global divisions reflect genuinely new developmental dilemmas. Low-income nations could consider their interests threatened by a global technological revolution in agriculture; this concern was explicit in Brazil's early attempt to compete with the US and Argentina by adopting transgenic soy. In New Delhi, the cliché one hears is: 'we missed the industrial revolution, we cannot afford to miss the information revolution'. From this reading of national interest, the very existence of biotechnology puts pressure on the developmental state to make new choices. ${ }^{8}$ Those at the bottom of the global hierarchy could, however, and sometimes do, see transgenics as a new dependency trap - or a risk to exports to Europe and Japan rather than a source of progress.

Poverty has figured prominently in conflicts over the place of genetic engineering in development strategy. India's then-Prime Minister Atal Bihari Vajpayee sketched the pro-poor developmentalist state 'vision' of 'shaping biotechnology into a premier precision tool of the future for creation of wealth and ensuring social justice especially for the welfare of the poor'. Biotechnology is to fight obdurate diseases, increase agricultural production, combat nutritional deficiencies and protect the environment (Department of Biotechnology, 2001). Any and all of these outcomes could be pro-poor if realised. Public intellectuals in India have written of 'seeds of death' (Shiva et al., 2000). Both supporters and opponents of transgenics have a poverty story to tell. Proponents have resurrected the Reverend Malthus in a view of aggregate food security that is often global: 'feeding a hungry world' is the corporate expression. Per Pinstrup-Andersen and Ebbe Schiøler, in a book that won the World Food Prize for 2001, conclude: 'once again Malthus's clash between population growth and food production looms threateningly on the horizon'.

In the optimistic scenario, expanding the production possibilities frontier with transgenic crops offers special advantages to the poor. Food scarcity prices poor consumers out of the market. For poor producers, seeds represent a divisible technology, in theory scale-neutral (Lele, 2003). Certain transgenic crops may even alleviate some financial vulnerabilities of the small farm: transgenic seeds such as those containing a gene from the common soil bacterium Bacillus thuringiensis hence the ' $B t$ ' designation - substitute a plant's own biological processes for cashintensive inputs such as pesticides. Cash-intensive inputs differentiate farmers along lines of wealth and connections; bad harvests often produce crippling debt through such intermediaries as usurious pesticide merchants, leading to widespread farmer 
suicides in India in $1998 .{ }^{10}$ Typically less able to tap inexpensive credit through social standing or political connections, the poor farmer is especially eager to reduce upfront cash expenditures. If the technology works, the question then turns to the price of seeds, and thus on the intellectual property contained therein.

Opponents of transgenics argue that it is precisely the most vulnerable people who will be most at risk; critiques often begin with intellectual property (Shiva, 2001). Biotechnology is held to enable new potential for monopoly control of seeds; it simultaneously enables global bio-piracy that plunders genetic resources of indigenous peoples and poor nations to make corporate property (Shiva et al., 2000; Shiva, 2001). Poor farmers, in this view, will be crushed by bondage to multinational monopolists, re-subordinating poor nations to neo-colonial control. The most excoriated mechanism has been 'terminator technology', widely (but falsely) charged to Monsanto, the lightening rod of global protest. Critics also see the poor as threatened by environmental degradation, unsafe foods introduced through foreign aid and public distribution systems, or allergenicity from novel proteins (Altieri, 2001; McHughen, 2000: 160-169; Sharma, 2004; Shiva, 2000; Winston, 2002: 107-129).

What unites authors in this collection - scientists and social scientists alike - is conviction that these are questions of great consequence and are amenable to empirical treatment, common practice notwithstanding. Being wrong about transgenics could have adverse consequences for the poor - both poor nations and poor individuals. If opponents of transgenics are correct, but proponents win politically, lives of the poor could deteriorate further. If proponents are correct, but critics win politically, the poor would be denied significant opportunities for improving their lives. Precautionary approaches are therefore not costless: the status quo is hardly risk-free for the world's poor. Proponents of genetic engineering argue that alternatives to some technical advances are more costly, slower, less certain, or impossible.

Honest science is Promethean: there can be no proof that all risks are known, or that current knowledge will not be undermined by new findings. For this reason, science often loses politically to the ominous uncertainty of Pandora's jug: fear of unknown unknowns (Herring, 2001).

\section{II. 'GMOs': The Political Biology of Labels}

Almost universally, opponents of genetic engineering label its products 'GMOs' for 'genetically modified organisms'. Thus develops market segmentation and a niche for 'GMO-free' labelling on grocery shelves and export baskets. 'GM-free zones' crop up in southern Brazil, but also in California. The designation 'GMO' posits and reifies a category, and thus a niche for mobilisation and product differentiation, where many biologists would find none - an artificial distinction. Genetic modification is the history of agriculture. All existing crops are genetically modified that is the purpose of plant breeding, which has been with us in a more or less scientific form for over a hundred years, and with us as a species for at least 6000 years. The current distribution of plant species cultivated for food and fibre has involved radical and purposive reduction of biological diversity for instrumental human ends. We would otherwise be, as a species, unable to feed ourselves. 
Plant breeding modifies genomes - there would be no point to it otherwise. Conventional techniques of genetic modification are often inconsistent with an idyll of Gregor Mendel puttering with his peas. In addition to familiar and now naturalised techniques of selection and crossing, the conventional repertoire includes more invasive and radical techniques: emasculation; intergeneric crossing (of unrelated plants of different species - for example, triticale, a cross of wheat and rye by conventional breeding); embryo rescue; haploid breeding and induced mutation that produces potentially useful genetic variations, and mostly fatal ones, by means of toxic chemicals or radiation. ${ }^{11}$ Recombinant DNA technology - moving a specific sequence of DNA from one place, or species, to another - expands the scope of plant breeding, producing alterations more quickly with less unwanted (and unknown) movement of genetic material. This technology is appropriately called genetic engineering, the product of which is a transgenic organism. 'Transgenic' is a more precise designation of organisms that result from rDNA technology: a biological category, rather than a political one.

Which plant breeding techniques should be considered natural, or dangerously unnatural, is an emotionally charged and non-negotiable vector of global disputes. Whether genetic engineering represents one end of a continuum of plant breeding or a radical departure separates the discourse of Frankenfoods from the stance of the US Department of Agriculture on 'substantial equivalence'. Though the term 'GMO' is now so embedded in policy and political discourse that virtually everyone uses it, it is important to underscore its biological ambiguity and political loading. It is recombinant DNA work that has energised the debate, because of its unique potential and consequent susceptibility: organisms believed to be impossible in nature.

Segmentation of global markets, driven by diverse interpretations of evidence and risk, creates strong interests in maintaining distinctions. A new global market niche for 'GMO-free' food joins organic products. This distinction has consequences for farmers. Papaya, for example, was genetically engineered to stop the ring-spot virus that was devastating crops in all papaya-growing countries. The transgenic was developed by two universities, Cornell and Hawaii, not by corporate giants. Adoption was rapid, and did not follow the three stage S-curve familiar in technology adoption, wherein larger farmers appropriate innovators' rents because they can stand more risk and command more resources. Rather, both in numbers and acreage small farmers dominated large (Gonsalves et al., 2007). Rapid adoption was driven by what might be termed the insulin effect: saving the plants took precedence over ideological distinctions. What eventually hurt small farmers who adopted transgenic papayas was not failure of the technology, nor intellectual property, but Pandoran logic: regulatory exclusion of transgenics from their major market, Japan. ${ }^{12}$ In a deeply ironic outcome, the beneficiary of Japan's restrictive policy was the transnational Dole, the world's largest producer and marketer of fresh fruits and vegetables.

There is nothing comparable in response to genetically engineered pharmaceuticals: zones for 'GMO-free' medicines. There are both biological and political reasons for this divergence. Genetic engineering creates uncertainties, perhaps risks, in agriculture that are less likely in laboratories. Genes will travel through agroecological systems, with unpredictable results. The practice of 'pharming' - the use of 
transgenic plants as factories for production of commercially useful chemicals - blurs these boundaries and represents a higher threshold of risk even for techno-optimists (Thies and Devare, 2007).

Some transgenic questions are thus genuinely new. Yet the intense controversies resonate with fundamental developmental questions - the telos of societal change, Promethean promises and threats of novel technology, distribution of benefits and risks differentially across segments of society. For many in the development community, the very question of benefits for the poor from transgenics is unthinkable: an instrumental ideological cover for corporate globalisation. Empirics thus far do not bear out their pessimistic scenarios. Yet their concerns warrant our collective attention if we are serious about anticipating consequences and clarifying conditions under which pro-poor outcomes are possible. The public and political discourse around biotechnology has largely taken a dichotomous and generalising form. We collectively seek to disaggregate where needed, while drawing larger pictures when possible.

\section{The Emergent Consensus: From Terminator to Toolkit}

An optimistically evoked 'international community' repeatedly declares global commitment to poverty reduction. The very existence of absolute poverty constitutes an ethical imperative to apply new knowledge - including plant science - to alleviate limits on human potential (Nuffield Council, 1999). Ethical choice presupposes knowledge, which is difficult to accumulate at the frontier (Leissinger, 2000). Howarth Bouis in this issue of Development Studies notes one of the many moral imperatives that make precautionary or obstructionist stances problematic in ethical terms: 'Globally, about 3 million children of preschool age have visible eye damage owing to a vitamin A deficiency. Annually, an estimated 250,000 to 500,000 preschool children go blind from this deficiency and about two-thirds of these children die within months of going blind'. Supposing 'Golden Rice' could reduce that catastrophe, even marginally, what evidence of risk from transgenic rice that alleviates vitamin A deficiency would justify denial of this technology?

Despite continuing opposition to 'GMOs', the terms of debate have clearly changed through acceptance of transgenic crops by more international organisations, farmers, and the epistemic community of agricultural scientists. Endorsement of biotechnology - including positing of benefits specifically for the poor - by the UNDP in its 2001 Human Development Report - 'Making technologies work for human development' - stunned some NGOs that had counted on that organisation for support of alternative development thinking (Kothari and Chawla, 2002). The UNFAO (2004) report on the State of Food and Agriculture 2003-2004 endorsed genetic engineering specifically for the poor, joining the position of the Consultative Group on International Agricultural Research of the World Bank (CGIAR). A recent report by WHO (June, 2005) reviews a great deal of science and concludes there are significant benefits to be obtained, especially in regard to health and nutrition in poor countries. Farmers' positive agronomic experiences would seem to be the reason for continuous expansion of acreage, crops and farmers; these data are tracked in publications of the International Service for the Acquisition of AgriBiotech Applications (ISAAA) typically authored by Clive James. ${ }^{13}$ ISAAA's annual 
accounting has become the reference of record. Yet even this sharply upward sloping curve significantly understates transgenic adoption: illegal, unregistered, graymarket stealth seeds are cropping up in many settings but cannot be fully documented. ${ }^{14}$ The discovery of transgenic crops in fields where they are not supposed to be - either in the bio-safety sense of being approved for planting or in the bio-property sense of violating proprietary claims - indicates substantial undercounting in official sources. We are reminded again that data are social products, the conditions of their production determining their relation to reality (Herring, 2003b). Farmers seem to be voting with their ploughs, whether or not biosafety committees and Monsanto confer their blessings.

Developmental professionals have increasingly agreed to something like a standard narrative of biotechnology. ${ }^{15}$ It is an optimistic but cautious consensus. Per Pinstrup-Andersen and Ebbe Schiøler's Seeds of Contention won the World Food Prize in 2001; it is indicative of the dominant narrative. This consensus departs both from the apocalyptic vision of the many NGOs opposed even to testing transgenic crops and from the transparently instrumental propaganda of multinational firms selling seeds. The metaphor of the 'toolkit' is telling: transgenics will not solve the problem of 'world hunger', but represent a new tool, just as many traditional tools are proving either inadequate or come with too many cumulative externalities - particularly environmental. Whether or not this new tool should be used, and under what conditions, goes to the heart of representation, reflecting the global rift of biopolitics. Participation is increasingly valued in developmentalist logic: who speaks for the poor? Pinstrup-Andersen and Schiøler claim to represent no one, but state that 'too many well-to-do individuals and groups from Europe and North America have taken an unacceptably paternalistic position, claiming to represent the interests of the developing countries and to know what is best for the poor within these countries'. The 'almost silent majority' of people in low-income countries are not being heard (Pinstrup-Andersen and Schiøler, 2000: xi).

Using the right tools is no simple task in this consensus; existing incentive structures, direction of research and property configurations augur ill for the poor. The sharp decline in the ratio of global public sector to private-sector agricultural research means that multinational firms dominate. Yet there is in principle no reason that public sector research could not yield results comparable to those of the private sector. Research and development costs are daunting, but large nations such as China, India and Brazil have public sector institutions that can operate at the technological frontier. The first field trials of transgenics were approved in 1987; globally, more than 11,000 field trials of 81 transgenic crops have been approved. The single most tested crop is maize (corn), followed by canola, potato and soybeans (Pray and Naseem, 2007, Figure 3). Soybean trials rank fourth, tied with cotton at 7 per cent each. Transgenic rice is both officially and illegally undergoing field tests. Yam has not been certified for field trials, but other 'orphan commodities' - for example, bananas, sweet potato, lentils - have all received approval for field trials in at least one country each. The direction of change is not toward consolidation and monopoly, but toward multiplication of actors and crops.

Dominance by multinational firms has been important politically, but has no necessary connection with modern biotechnology. Public investment in biotechnology is held to be justifiable in the emergent consensus because intensification along 
lines of the status quo is unlikely to be sustainable. After weighing logical pros and cons and looking to some evidence, Pinstrup-Andersen and Schiøler conclude that 'the organic approach, while certainly a worthwhile option in regions with the space, the labor and the consumer purchasing power ... is not a cure-all' (2000: 79). Biotechnology could bypass some of the worst externalities of the 'green revolution' while avoiding the yield limitations of low-input agriculture (Conway, 1997).

The optimistic scenario is hedged by Promethean concerns: new organisms necessitate surveillance and control. The final chapter of Pinstrup-Andersen and Schiøler's book is tellingly entitled 'Moving forward: handle with care'. The authors underscore problems of concentrated control of technology by unaccountable firms; they endorse ethical scrutiny of each step in evaluating transgenics; they stand for 'free and informed choice' for consumers and farmers, and, emphatically: 'extermination of a terminator' (2000: 135).

'Terminator technology' has been perhaps the most effective weapon for mobilising global opposition to transgenics; ${ }^{16}$ it is not surprising that the standard narrative disavows it. The terminator creates a bio-cultural abomination: a plant that cannot produce viable seeds. Opponents charged that gene use restriction technology [GURT] would increase costs to farmers, force them to buy more products (gene activators) and prevent saving of seed for future planting. Though the terminator has been emblematic of the political dramaturgy deployed against biotechnology, the deep irony is that, as Pinstrup-Andersen and Schiøler note, gene use restriction technology would be the only certain means of preventing horizontal gene flow - the major environmental risk. To date there have been no applications for field trials, nor field testing of terminators. Of greatest importance to small farmers, there are compromise technologies that require activation only if the farmer wants to retain the engineered trait; otherwise, the seed reverts to pre-transgenic genome and can be saved, absent the inserted trait. ${ }^{17}$ This concept averts the most serious environmental uncertainty and is compatible with concerns for seed choice and seed saving among poor farmers.

The standard narrative then has two major components that temper optimism about pro-poor outcomes: Biosafety and Bioproperty. With assumptions about adjustments to bioproperty, and establishment of biosafety institutions, the probiotech narrative acknowledges major points of critics and answers them. But there is a third assumption less acknowledged or discussed: Biopolitics. Recombinant DNA technology introduces a deep ideational divide on the nature of the natural. Benefits for the poor frequently depend on coalitions that use political means to countervail their structural disabilities in markets: minimum wages, social security, nutrition programs, health insurance, transfer payments. These coalitions support public goods especially important to the poor - clean water, education, law and order. Such coalitions are rare and fragile (Moore, 2003); they often divide explicitly on transgenic organisms. Howarth Bouis (2007) in this collection writes confidently that biofortification has the great advantage of not needing to rely 'on behavioural change as a condition for success ... [like] ... adding fluoride to drinking water in developed countries'. But in Ithaca, New York, home of Cornell University, a leading centre of science research and education, and inhabited by a notably welleducated and progressive community, there is no fluoridation of water, despite widely accepted benefits, particularly for the poor. Even professional associations of 
dentists, for whom this public good reduces private income, support fluoridation of water. It is politically impossible to put fluoride in the water in Ithaca for fear of poorly specified risks; Pandora has left her mark everywhere.

Citizens encounter biotechnology through a hyperbolic and distorted discourse; scientific literacy is low. The Frankenfish tomato-with-flounder-genes had a robust life in popular junk-science but was a hoax (McHughen, 2000: 14-16). 'Terminator technology' cotton did not exist in India but frightened both public and some farmers, though the discourse ultimately departed too far from farmers' experience and interests to be sustainable (Herring, 2005).

Public caution is thus understandable. And there are good reasons for mass publics to lack confidence in science. The Merck Vioxx (rofecoxib) episode is illustrative. Merck is charged with suppression of data, in collusion with regulators, causing tens of thousands of unnecessary deaths; the firm now faces about 7000 court cases in the US. One scientific study Merck cited in its defence of Vioxx has been discovered to contain falsified data: the prestigious New England Journal of Medicine, in an unusual step, posted an editorial disclaiming the article, which it had published five years earlier. ${ }^{18}$ Dr David Graham, associate director for science in US Food and Drug Administration's office of drug safety, testified in Congressional hearings that the number of additional heart attacks and strokes could be 139,000, with 55,000 deaths. Graham explicitly argued that data were available to predict this catastrophe but were ignored by the FDA. Senate Finance Committee Chairman Charles Grassley, Republican of Iowa, rather quaintly termed the relationship between regulators and regulated too 'cozy'.

Critiques of biotechnology posit hasty, self-referential science dominated by symbiotic relationships with regulators and producers (Winston, 2002: 58-82). Moreover, there is no assurance that research driven by the profit needs of corporations or wealthy farmers will coincide with the needs of the poor. There is little private incentive to produce for small markets of poor people, especially when the political climate for acceptability of transgenic crops in low-income countries is uncertain or hostile (Potrykus, 2004). Orphan crops could thus well join orphan drugs as instances of market failure. Addressing market failures that produce human misery is a central legitimation of development policy. The standard narrative thus converges on redirection of biotech research and development as necessary conditions for reaching the poor. Getting the institutions right is then a necessary condition for purposive pursuit of poverty-reducing outcomes (Cohen et al., 2003). Where both Promethean and Pandoran discourses mislead is in failure to disaggregate both biotechnology and poverty: across economies, social stratification systems, crops and agrarian structures.

\section{Disaggregating Pro-Poor Claims}

Poverty is defined variously, but a biological construct seems least subject to measurement noise and subjective entanglements. Early treatment of 'absolute poverty' defined a human condition so limited that the genetic potential of the species is denied to individuals. This is an outcome notion of poverty: do people have the means of realizing the potential of the genes with which they are universally born? 
Much of the debate on biotechnology has been about farmers, but most of the world's poor do not control food-producing land; their relation to the genomics revolution is through food prices, labour markets, biofortification of staples, bioremediation of environmental hazards, and possibilities still on the drawing board. Though the poor constitute a heterogeneous category, some primary desiderata are universal:

(a) Incomes: For farmers, the question is net returns from new seeds, which depend on an interactive effect of yields and costs. Net employment and wage effects (shadowing productivity gains) relative to food prices are most important for the most vulnerable poor: field workers who have only labour to sell.

(b) Nutrition: The poor need more affordable and more nutritious food to improve their health and to live longer and more productive lives. Low-cost food is obviously important; yet the poor consumer's gain can be the poor farmer's loss unless total factor productivity on farm rises.

(c) Environmental integrity. More often than for the rich, livelihoods of the poor depend on ecological integrity; environmental degradation affects most quickly and seriously those with the least flexibility in life choices.

This simple accounting does not exhaust the needs of the poor - one thinks of land, shelter, medical services, political access, cultural acceptance, and personal security among others. Nor should consideration of transgenics obscure more fundamental levers: the international regime of agricultural subsidies and protectionism in rich countries, for example, has a much larger impact on incomes of the rural poor than any transgenic crop. Yet technology may matter fundamentally.

\section{Income}

Analytically simplest, at first blush, is the question for farmers: under what conditions does genetic engineering allow scale-neutral deployment to raise incomes of small and marginal farmers? Scale-neutral technical change can in theory lower the size threshold of a viable farm; the declining size of holdings worldwide underscores the urgency. The most marginal farmers are most at risk from potentially remediable biotic and abiotic stresses on crops, as they are driven to the most difficult land with the fewest resources for amelioration; water is illustrative (Nuffield Council, 2004: 3.42).

Most evidence from the field is limited to a few crops developed for use in highincome countries: glyphosate[herbicide]-resistant soybeans, corn (maize), canola; insect-resistant corn and cotton. Even so, there is evidence for scale-neutral transgenics giving superior net-returns. The clearest evidence is probably from $\mathrm{Bt}$ cotton, where small farmers have increased net income through two mechanisms: less cash expenditure on insecticides and better protection from pests, hence better yields. ${ }^{19}$ David Zilberman and his co-authors (2007) explain theoretically why this outcome is predictable, and widespread. Unlike lumpy capital investments such as tractors or tube-wells, transgenic seeds - both in theory and on the ground exhibit what Rogers (1995) calls 'trialability': experimentation with an innovation 
may be done on a limited basis. Florence Wambugu (2000) stresses that the technology package is in the seed itself, allowing existing skills to be applied without stratifying extension infrastructure and knowledge hierarchies. The empirical evidence that small farmers can take advantage of biotechnology to avoid debts for inputs, provide some insurance against crop failure and raise production has been vetted by development organisations such as UNDP (2001) and the UNFAO (2004).

Evidence to date does not indicate widespread resistance of small farmers to biotechnology where it is available and affordable; quite the contrary, smuggling and creolization crop up where transgenics are unavailable or unaffordable. Gray-market seeds spreading underground, farmer to farmer, in Brazil and India, for example, eluded both state managers of biosafety and corporate enforcers of property rights (Herring, 2007). Unless one assumes small farmers to be irrational, this evidence suggests income-positive effects. The worst-case scenario would be for improved yields from transgenic crops to depress farm-gate prices for poor farmers who lack access to the technology but suffer from backwash price effects; this outcome was one of the failures of the 'green revolution' in poverty reduction (Lipton forthcoming). The outcome for poor producers could then be negative even as the outcome for poor consumers would be positive. Should commercially driven export economies continue to adopt cost-saving biotechnology, farmers in resisting nations will face new competitive disadvantages piled on top of the subsidy and protectionist market-rigging of wealthier states.

The exception to scale neutrality must be when the cost-of-entry barrier is too high for poor farmers in imperfect credit markets: for example, expensive seeds from profit-maximising monopolists. Concerns with dominance of private capital in bioproperty are thus warranted, but critics have exaggerated the burden of patents, private-property claims and technology fees. There is a here a curious rejection of simple prudence: farmers will not buy seeds that do not increase margins. Even those farmers who pay royalties are expanding acreage, suggesting positive income effects. Bioproperty has proved much more fluid, contingent and variable than opponents of the technology had feared, as discussed in the section on institutions below.

Global segmentation of markets reflects differential reach of Pandoran logic, and has poverty implications. If the United States Department of Agriculture is correct in its stance on 'substantial equivalence', market discrimination is artificial and wasteful. Though there is softening of European hostility to transgenics, it is not yet clear how product identity preservation and labelling in the global market will affect opportunities for poor farmers. Labels such as 'organic' provide market niches for labour-intensive farmers to sell at premium prices in rich countries. But 'organic' in the US legally precludes transgenic seeds, whatever the agro-ecological practices on farm.

The most obdurate problem of rural poverty is that of landless workers who must find wage employment on whatever crops need labour. They are put at risk by crop choice, but have no voice. What is a livelihood for the labourer is a cost for the farmer. In high-wage agriculture, labour-saving technologies are profitable and will draw investment and development. Herbicide-tolerant transgenics account for a majority of the global transgenic acreage; farmers save money and labour under certain agronomic conditions (e.g., Nuffield Council, 2004: 40-42). Reduction in 
aggregate demand for labour under many agrarian conditions either destroys livelihoods or puts downward pressure on wage rates or both. Moreover, the rural poor who depend on weeding for a livelihood are frequently those cumulatively disadvantaged across dimensions of social stratification: women, depressed castes, ethnic minorities, migrants. Under those conditions, if herbicide-resistant crops are desirable on other grounds - soil conservation, for example, or use of less toxic herbicides - a pro-poor strategy would necessarily begin with simultaneous discussion of land reforms, rural public works, food subsidies, and other mechanisms to avoid making the poor pay for technology-induced profits (Herring, 2003a).

Labour-displacement is caused by a trait of a variety, not of the method of plant breeding. Herbicide-resistant crops can be bred by traditional means as well as transgenic. For poverty analysis, what matters is the effect of the variety on demand for labour, not whether the varietal characteristic was achieved through transgenic or conventional breeding.

If transgenic crops do reduce demand for labour, poverty effects would be differentiated by agrarian structure. Where holdings are small and relatively equal, as in China, smallholders would be saving their own labour, not depriving others of employment; this seems to be the case with $B t$ cotton. Poor farmers improve their position by freeing up time for other crops or other jobs, as few small farms provide subsistence on their own. Where holdings are larger and less equal, as in India, labourers would lose work applying pesticides. ${ }^{20}$ Then the critical question becomes: are wage losses in chemical applications compensated by more harvest labour if yields increase, and by safer ground water and less exposure to toxins? If net wages are lost, but health improves, a difficult trade-off arises. This trade-off depends on variations in wage systems: for example, when wages are based on weight harvested - rather than a daily sum - income increases with yield and ease of harvest, as sometimes occurs in $B t$ cotton (see discussion in Roy, Herring and Geisler, 2007). Moreover, whatever the effect on demand for spraying labour, protection from crop loss has implications for labour: there are no harvesting wages if crops are destroyed by bollworms. It was only fields of $B t$ cotton that survived the 'bollworm rampage' of 2001 in Gujarat (Visvanathan and Parmar, 2002). To the extent that transgenics reduce risk of crop failure, they reduce risks for the landless poor, as well as farmers.

Where farm labour is either scarce, or mostly supplied by farmers on their own land, ability to control weeds enhances yields, returns to labour, and opportunities to take on more land for cultivation when available. One should not assume that poor households have endless supplies of labour, nor that they need little cash. Increasingly, neither is true. Florence Wambugu (2000) has stressed labour constraints as limiting factors in African agriculture. The objective interests of the rural poor in India and Africa may then diverge in herbicide-resistant technology. But even in India, demand for rural labour is highly seasonal: an aggregate surplus of labour, indicated by insecurity and poverty among workers, does not rule out labour shortages in times of peak demand. When farmers complain of short labour supply, they often mean that they cannot hire in discrete bundles of time separated by enforced idleness at a wage that gives them a profit but leaves labourers below the poverty line in annual income (Herring and Edwards, 1983). Disaggregating agrarian structure and crop traits indicates the kind of patient empirical research that will be 
necessary for meaningful poverty analysis for particular agrarian systems and particular crops.

\section{Health and Nutrition}

Most of the global poor are not farmers. The overwhelming facts of poverty are insecurity and restricted options: food comes first, and consumes a larger share of expenditures the poorer one is. Moreover, food expenditures of the poor tend to be weighted towards staples rather than fruits, vegetables and animal protein. As deadly as protein-calorie malnutrition is, nutritionists increasingly recognise that micronutrient deficiencies may be equally or more debilitating. The often imperceptible 'hidden hunger' of micronutrient deficiency reduces energy, stunts growth, impairs cognitive development, and raises morbidity and mortality rates (WHO, 1999, 2001). The potential of bio-fortification of staple food crops - of which pro-vitamin A Golden Rice is the poster plant - figures heavily in claims for the life-saving potential of biotechnology. Engineering staple plants to make bioavailable nutrients for those who cannot afford diversified diets may be superior - in cost and sustainability - to alternatives such as supplementation or fortification of processed foods. The situation in the South reverses that in the North. Consumers in the global North benefit little if at all from transgenic foods, but have been the guinea pigs for testing allergenicity and other putative health risks. In the global South, malnutrition and poor health are more common, corrective health care less available, ability to alter diets less robust (Bouis, 2007).

Biofortification may prove to be the most significant contribution for the poor; crops can be destroyed by natural catastrophe, recessions reduce incomes; international market rigging can reverse gains from higher productivity. But so long as adequate entitlements to food staples can be maintained, nutritional enhancement of those staples contributes directly and significantly to welfare. Spatial disaggregation is important as well. Conventional supplementation and fortification programs may not reach the isolated poor in remote areas, or do so only at great expense and without regularity. Biofortification of staples specifically targets those most at risk. Yet much is unknown. How practical are nutritional enhancements in different agronomic regions and crops? Will consumers accept transgenic foods? Will farmers grow bio-fortified crops? Are there dangers in over-dosage of specific micronutrients for specific individuals?

Howarth Bouis analyses the potentials of biofortification in three breeding substrategies that may be deployed separately on in combination: (i) reducing the level of antinutrients (for example, phytic acid) in food staples, which inhibit the bioavailability of minerals and vitamins; (ii) increasing the levels of nutrients and compounds that promote the bioavailability of minerals and vitamins; and (iii) increasing the mineral and vitamin content. The effort to improve the micronutrient content and/or bioavailability of commonly eaten foods does not substitute for urgent efforts to provide the means for a better and more varied diet desired by but too expensive for the poor.

Claims that transgenic crops are themselves a threat to health are persistent but without validation. For its State of Food and Agriculture 2003-2004, the UNFAO (2004) evaluated a large body of scientific literature and found no evidence of any 
danger to human health from transgenic food plants currently being grown. Similar findings characterise the WHO's recent (June, 2005) report. Modern Food Biotechnology, Human Health and Development: An Evidence-based Study. The Nuffield Council report (2004: 4.47) concluded from a survey of existing literature and that 'there is no empirical or theoretical evidence that GM crops pose greater hazards to health than plants resulting from conventional plant breeding'. That report goes further: biotechnology may reduce known dangers in conventional foods from substances such as mycotoxins, glucosinolates, and alkaloids. Because of higher standards of testing, it is fairly certain that no one will die of $B t$ maize, but an analysis published by the US Centers for Disease Control finds that 'foodborne diseases cause approximately 76 million illnesses, 325,000 hospitalisations, and 5,000 deaths in the United States each year' (Mead et al., 2004). Regulatory attention to vague and hypothetical risks of new crops has opportunity costs for attention to clearly documented threats from conventional foods.

\section{Environmental Integrity}

The poor depend more on the environment for livelihoods and have fewer exit options than the rich. Critics of biotechnology have conjured ecological disasters; Vandana Shiva and colleagues (1999) wrote that the 'terminator' would 'terminate biodiversity' if India allowed even test trials of $B t$ cotton. Predictions of gene flow and superweeds conflate to biological Armegeddon (Winston, 2002: $235 \mathrm{ff}$; McHughen, 2000: 261-262).

The normative question for any technological change is always: compared to what? Modern agriculture poses well-known, and almost certainly unknown, risks; the struggle against pests and weeds has reached desperation levels in many settings (Pimentel et al., 1998). Widespread cultivation of transgenic plants in North and South America has produced no evidence of even incipient environmental disasters (Thies and Devare, 2007). Against the Armageddon narrative of critics, some scientists posit environmental benefits from transgenics (Horsch and Fraley, 1998). Pinstrup-Andersen and Schiøler note that increases in aggregate agricultural production have historically come from two sources other than improved seeds conversions of landscapes and application of chemicals to fields. Both have ecological consequences. Conversions fragment and destroy habitats and disrupt eco-system services. They argue that 'without the scientific breakthroughs associated with the Green Revolution, the increase in India's wheat production alone between 1966 and 1993 would have necessitated ploughing another 40 million hectares of land' (2000: 20). Raising production requires either more per acre or more acres; the source of more acres is typically ecological destruction.

All agriculture carries risks for ecological systems (Conway 1997: 86-107, passim). Mark Winston notes that 'there are hundreds of examples of genes from domesticated crops jumping to feral weeds ... twelve of the world's thirteen most important food crops have sent genes into wild plants through pollen transfer'. One of the banes of my teenage years was Johnson grass (Sorghum halepense), an invasive and destructive species that exchanges genes with cultivated sorghum (Sorghum bicolour). ${ }^{21}$ Franken-weeds resulting from plant gene flow were theoretically possible long before genetic engineering, though most gene flow reduces rather than enhances 
fitness of subsequent generations of feral plants. The relevant question is of incremental risk: how much more risk, if any, does introduction of a transgenic variety entail in comparison with a variety modified by other means?

The poor are especially vulnerable to hazards of modern agriculture; they cannot afford to be selective about what jobs they take. If someone is going to don a backpack sprayer and walk unprotected and often half naked while spewing toxins, it is likely that he will be poor. If anyone is going to drink contaminated surface water, or water from shallow wells, she is most likely from the bottom of the social hierarchy, not the top. Here the claim of $B t$ technology, especially in cotton - a crop particularly prone to pests and toxins - is compelling. Surveys of 400 farmers in northern China found that adoption of $B t$ cotton led to dramatic reductions in use of dangerous organophosphate pesticides and an FAO class II pyrethroid, resulting in significant reduction in incidence of pesticide poisonings (Pray et al., 2002). There is evidence indicating improved farmer health in $B t$-protected fields as opposed to sprayed fields (Huang et al., 2002; James, 2002: 138-147, et passim). Reduction of pesticide spraying can be expected to help curb the epidemic of pesticide poisoning (Jeyaratnam, 1990), conserve some water, and reduce the wholesale destruction of both beneficial insects in the fields and wildlife that depend on those agro-ecological niches. Insect-resistant crops also measurably lower contamination of food crops by mycotoxins produced by opportunistic fungi that infect wounds made by feeding insects (Munkvold et al., 1999).

Though some critics expect biotechnology to 'terminate biodiversity' (Shiva et al., 1999), no mechanism is discernible. The purpose of conventional agriculture is to reduce diversity in the fields, removing competitive plants from those the farmer wants to thrive. Zilberman and his colleagues (2007) find that there are reasons to expect crop genetic diversity not to decline with adoption of transgenics; they cite the evidence of Klaus Ammann, who 'finds that genetic uniformity of crop varieties has decreased by 28 per cent during the period of introduction of transgenic varieties in the US. The evidence suggests that introduction of GMVs around the millennium did not have significant effect on genetic uniformity'. It is possible that the net effect of rDNA breeding would be greater crop diversity because of faster results, more precise breeding for niche applications, and illicit on-farm breeding associated with creolisation and stealth seeds. ${ }^{22}$

Generic toxins kill indiscriminately; non-target fauna - some of which prey on pests - suffer high casualty rates - as do their predators, spreading costs up the food chain. Bt crops target only a narrow range of Lepidoptera: the insect must attack the plant to receive a dose of toxin. There is a kind of natural poetic justice in targeted endotoxins. The selectivity possible in transgenic endotoxins should improve biodiversity of fauna in comparison with spraying of generic toxins. There is evidence for this outcome in China: increased number of insect species in $B t$ cotton fields (Pray et al., 2001; Pray and Naseem, 2007).

Disaggregation produces complex analytics that require significantly more empirical research than exists; in this sense, the serious literature on transgenic crops and poverty is just beginning. ${ }^{23}$ Thies and Devare, in analysing one of the poster animals in the gene wars - the monarch butterfly [Danaus plexippus L.] as affected by $B t$ toxins - emphasise that there will be variance across transgenic crops modified by different genetic events [particular gene insertions]. Effects can be 
understood only by disaggregating time: plants flowering at different times have less risk of gene flow in comparison with simultaneously flowering plants, for example. Ecological effects then depend on varietal differences. It was for this reason that one cultivar of $B t$ maize (event 176) was not re-registered with the US Environmental Protection Agency in 2001. The variety contains a pollen-specific promoter and consequently exhibits significantly higher pollen toxin levels than $B t 11$ or MON810 $B t$ corn. Only what Thies and Devare call 'the dialectics of normal science' will sort out these effects, crop-by-crop, event-by-event.

Pitting certain benefits against uncertain dangers presents a difficult publicchoice dilemma. When probability distributions are known, risks can be assessed rationally - for example, whether to fly or drive. With transgenics and environmental change we have uncertainties, not probability distributions. It is not helpful to say, as techno-optimists often do, that science should decide; there is no scientific means of placing values on uncertain outcomes. Risk aversions are not subject to refutation; some people fear airplanes, others fear rare diseases - no data will determine correct preferences. The only solution to this public-choice problem is interaction between democratic processes and biosafety institutions. The poor are the least likely to be effective in these deliberations under existing institutional arrangements. ${ }^{24}$

\section{BioInstitutions: Property, Regulation, Safety}

Property should figure prominently in any poverty discussion. Property enables the capture of income streams from innovation. If private firms are to invest in biotechnology, they expect returns, presupposing enforceable property rights. This functionalist argument for strong property rights is widely accepted in the standard narrative. Not surprisingly, the concept patent on the so-called 'terminator' was for a 'technology protection system'. ${ }^{25}$ But there is little money for technology fees on subsistence farms. Moreover, without the terminator, inability to control the technology and to enforce property rights on the ground limits commercial interest in biotechnology for the poor. Biosafety confounds problems with bioproperty. Regulatory delays tie up capital and introduce uncertainty. Limited market potential, fear of piracy and high regulatory costs are typically cited as disincentives for capital. The answer in the standard narrative is more investment by public sector institutions, where public interest - not private return - guides allocations. But as support for agriculture declines in aid budgets, and international institutions' budgets are stretched, would a transgenic initiative divert funds from higher priorities?

Pro-poor opponents of biotechnology argue that monopoly power will soak the poor for super-profits (Shiva et al., 2000), but the picture is more complicated. First, 'humanitarian-use' transfers of intellectual property, and segmentation of markets to permit poor producers to avoid fees charged to commercial producers provide a workable model (Lybbert, 2002). Extremely complex property claims in Golden Rice -70 patented technologies controlled by 30 institutions - were consolidated to privilege poor producers while allowing for fees on rich farmers (Kryder et al., 2000), under the control of a 'humanitarian board'. This outcome is for many proof of concept in plant breeding driven entirely by needs of the poor. There is also the public sector. China's public sector Bt cotton successfully competes with Monsanto's 
version locally and entered India by way of partnership with Nath Seeds. In India itself, public sector research is increasing significantly, though still far behind that of China. The analogy to pharmaceuticals seems clear: market-driven distribution with strong property rights does not serve the poor, but market segmentation and humanitarian intervention are not impossible, as with retroviral drugs in Africa. In addition to agreements for humanitarian use of proprietary technology, publicprivate partnerships, and public sector transgenics, farmer-created transgenics have emerged in opposition to global proprietary claims of multinationals. Property rights are not self-enforcing. Monsanto expends great energies trying to collect technology fees in Latin America, with spotty results; high prices of Monsanto's Bt cotton in India spurred development of the stealth-seed market, and led to demands to ban Monsanto's varieties - with success in one state. Some transgenes have spread so widely underground that they resemble open-access or open-source technology more than monopoly, more Linux than Microsoft. The transgenic genie is out of the bottle. ${ }^{26}$ Even in strong property regimes such as the US, Monsanto is forced into undesirable publicity - suing modest farmers even to bankruptcy - to increase compliance with otherwise unenforceable claims. Since it is impossible to catch everyone who violates contracts prohibiting replanting of transgenic seeds, Monsanto seeks to make examples of a few farmers for deterrence (Liptak, 2003: 18). Such strong manifestations of intellectual property have not proved practicable on a global scale for reasons of transactions costs, politics and law. To date, biotechnology has invigorated a vigorous anarchic and artisanal agrarian capitalism through the spread of stealth seeds, whereas global monopoly power of multinational property in biota is difficult to discern on the ground (Herring, 2007).

Bioproperty and biosafety regimes interact. The weak nature of bioproperty regimes on the ground means that if there is to be monopoly it will be through a strong biosafety regime. Strict control and testing regimes raise costs of seed development beyond what is affordable by small firms, enhancing the power of deeppocket corporations. If Monsanto cannot enforce its property claims in India, could Delhi's biosafety regime create de facto monopoly by prosecuting producers of underground $B t$ seeds? In theory, yes; in practice, no. India farmer and seed organizations have charged that biosafety officials had precisely this objective, and demand regularization of illegal transgenics, especially Navbharat 151 - the original stealth seed - and especially in Gujarat. Strong bio-property rights and demanding bio-safety regimes drive high prices of official seeds, and thus invigorate the underground market.

There are unresolved property questions spawned by genetic engineering: what can be owned? Where is the line between common and acceptable private property? (Kloppenburg, Jr. and Kleinman, 1987; Hilgartner, 2002). Firms recognize that these issues are not settled. Evidence does not support a super-profit gold-mine interpretation of biotech dominance: Pray and Naseem (2007) show that private firms are decreasing their investments in agricultural biotechnology, whereas public sector institutions in low-income countries are increasing investment. But the publicprivate distinction in research is often overdone in any event. Even conceptually, it is not clear that private investment precludes collective benefits from biotechnology. Michael Lipton notes that critics have a point in their claim that the poor are unlikely to benefit from the "focus, so far ... on "cottonseed and chicken-feed" (soy, 
yellow maize)'. But does the basic science not have implications beyond those seemingly humdrum products?

The standard narrative recommends redirection of and public participation in both research and property. This is happening, but is it not possible that the science itself will enable pro-poor outcomes, whatever the incentives directing research? Bt cotton, for example, helps free farmers from pesticide merchants and debt, independently of Monsanto's objectives. Who benefits from the global spread of transgenic crops? Pray and Naseem (2007) conclude from their analysis that the primary beneficiaries of increased revenues to date are not multinationals but farmers and consumers, even in countries that enforce strong intellectual property rights.

Is it possible that 'farmers' in general could benefit but poor farmers lose in the shift from public to private sector dominance of seed property? If transgenics require more upfront cash for technology fees than alternative seeds, wealthier farmers will be advantaged. The poor are less able to afford cash payments from savings and are excluded from or disadvantaged by credit institutions. They often pay more for credit. Precisely the same probabilities of lower ranking in the social hierarchy that make poor farm labourers especially vulnerable to income insecurity and nutritional crisis afflict small farmers in stratified agrarian systems (Herring, 1977). For these same reasons, to the extent that transgenes substitute for upfront cash costs, as in $B t$ substitution for pesticides, they are of special benefit to the poorest farmers; yield increases may well be highest on the poorest farms, reflecting prior inability to purchase sufficient inputs for want of cash or credit (Lipton, 2007). Creative credit institutions are in general of special importance to the poor, especially under conditions of technical change. ${ }^{27}$ In the more common scenario, lacking political power, connections, credit and cash, the poorest farmers would be better served by a cropping regime that substituted biological controls for purchased chemical controls.

Technology fees and their enforceability then matter greatly. Poor farmers would certainly lose if technology fees prove to be prohibitive - and enforced - and yields improve on farms of those who can afford the fees. 'Farmers' as a class could still benefit, but poor farmers would be caught in a backwash of lower output prices because of increased yields on adopter-farms, but with no reduction in input costs or increased yields on their own farms. Technical change in this scenario would accelerate agglomeration of ownership and the ruin of small farmers.

The final institutional caveat in the standard narrative is effective regulatory capacity for biosafety, linking far-flung villages to a global regime of the Cartagena Protocol on Biosafety of the Convention on Biological Diversity. Discussion of these institutions often conveys a certain magic-wand quality. The most difficult questions are without answers: How much regulation? Will regulation work? Are the results worth the costs? Thies and Devare note that in the US 100 times more is spent in technology development than in risk assessment and monitoring. Is this too high a ratio or too low, or, in the Goldilocks formulation, 'just right'?

What are the real threats to biosafety? Gene flow among plants is common; more critically, whole genomes are continually inserted into agricultural and other ecologies through invasive plants (Pimentel et al., 1998) and conventionally bred varieties. Invasive species are almost certainly a greater danger than flow of a single 
gene, which would have to increase the fitness of some wild relative significantly to be of any concern. The Center for Biological Informatics of the US Geological Survey estimates the costs of invasive species to be $\$ 138$ billion per year in the US (http:// invasivespecies.nbii.gov/). Where should the biosafety dollar be spent? There are many competing priorities; the poorer the country, the more poignant the trade-off. Should India tie up microbiologists in $B t$ cotton surveillance while biofortification research goes begging or invasive species wreak ecological havoc?

Biosafety regimes will certainly consume resources; will they work? Seeds are not only divisible as working capital - contributing to scale-neutral characteristics (Lele, 2003), and hence to poor-farmer income - but sufficiently divisible to evade the Panopticon assumed in official biosafety discourse. The original import of $B t$ cotton seeds into India was one-hundred grams; there are now millions of acres under dozens of unauthorised transgenic cotton varieties in the field - no one knows precise numbers. $^{28}$ Refugia set-asides are recommended to prevent development of resistance to endotoxin-producing transgenes such as $B t$; it is clear that small farmers would be especially disadvantaged by these requirements - and that many, perhaps most, ignore them. However, the science is imcomplete: if there are alternative hosts for the insects, as seems to be the case for bollworms in India, any refugia requirement is an unnecessary cost imposed on farmers and society alike. ${ }^{29}$ Identity-preservation measures for segregating and labelling transgenic crops are neither costless nor foolproof. In 1999, Aventis Corporation's StarLink corn hybrid, containing the $\operatorname{Cry} 9 \mathrm{C} \mathrm{Bt}$ gene for resistance to European corn borer, was discovered in corn products within and exports from the US. No ill effects from Starlink have been demonstrated, but the variety was approved only for non-human food uses. Nevertheless, food processors and distributors throughout the marketing chain were required to remove all products containing StarLink DNA, at an estimated cost of $\$ 1$ billion (Moose, 2003). This entire operation may well have been a complete waste of food and money.

Discursive reifications of both seed and state - or 'patents' and 'biosafety regime' sit uneasily with ground experience. Seeds are highly portable. Saved transgenic seeds and farm-to-farm exchanges undermine both bioproperty and biosafety regimes - a useful corrective to the presumption of monopoly power of multinational corporations, but troubling for the optimistic discourse of biosafety. In both Brazil and India, farmers have crossed transgenes from Monsanto technology to fine-tune local varieties, and save seeds to cut costs. Unauthorised and creolised $B t$ cotton seeds spread underground in India, undetected by the Genetic Engineering Approval Committee in Delhi (Jayaraman, 2001, 2004). Once it discovered these seeds through commercial rivalry - not its own devices - the GEAC proved essentially impotent. As a result, a kind of genetic anarchy evolved in India's cotton regions: packaged farmer-generated $B t$ crosses, F2 seeds from earlier crosses, and officially approved Bollgard varieties (21 as of June 2005), all competing for space in the fields at different price points (Roy et al., 2007). Oppositional discourse in both Brazil and India posited monopoly and dependence - premised in both cases on 'seeds of death' - and targeted Monsanto specifically. On the ground, Monsanto looked more like Gulliver than Goliath; biosafety law appeared as more aspiration than constraint. 'GMO-free zones' declared by popular organisations and governmental institutions seem quaintly fantastical. 
Brazil and India present special difficulties for environmental regulation: authority is divided structurally between centre and states in expansive federal political systems with long porous borders; significant power resides in multi-tier courts; farmers are courted by democratic regimes; bureaucracies are not immune to special pleading. Yet one can find comparable characteristics militating against enforcement in many political systems: penetrated or captured regulatory agencies, corruption, bureaucratic incapacity, local power of the nominally regulated. Surveillance of nature is no mean task, either macro or micro, whatever the claims of the 'high-modernist' state of James Scott (1998). It will be difficult given the skill repertoire of modal bureaucrats to distinguish transgenic plants from isogenic varieties. Moreover, gene police will be no more popular in villages than forest guards.

In the optimistic narrative, state technicians will be able to make for society the cost-benefit analyses necessary to decide which transgenics, when, and where. But there are also no probability distributions from which a true risk assessment can be derived and few means of stopping the flow of seeds that farmers want - short of the much-maligned but un-tested terminator. The regulatory regime of the Cartagena Protocol on Biosafety of the Convention on Biological Diversity will be costly and difficult to implement, particularly in the poorest countries, and perhaps ineffective. If benefits are captured by a subset of farmers and seed companies, but costs are spread to society generally, the case for transgenics is proportionately weaker on developmental grounds. If transgenics represent progress, caution or 'regulatory excess' has high costs for the poor. In the foreword to the Nuffield Council on Bioethics report (2004), Chairman Bob Hepple argued: 'It cannot be responsible to render a technology unavailable to those whose needs are urgent. Nor can it be responsible to be partisan in a debate where empirical evidence should be decisive in settling the question'. It is hard to argue with this sentiment, but unlikely that mere empirics will be decisive drivers in biopolitics.

\section{Biopolitics}

For transgenics to be incorporated into pro-poor development strategies depends on widely shared assumptions: an appropriate intellectual-property regime, pro-poor research priorities and bio-safety controls for environmental protection. Another assumption, seldom explicitly stated, is that pro-poor strategies for biotechnology are politically feasible. Because the poor are unlikely to be politically powerful, coalitions become critical (Moore, 2003; Herring, 2003a); these coalitions are mediated by politicised science in transgenic policy.

NGOs speaking on behalf of the poor have intermittently blocked or destroyed field trials designed to test transgenic crops. This phenomenon illustrates absence of even the most basic epistemological and methodological grounds for resolution of the politicised science of 'GMOs'. The political vulnerability of genetic engineering is acknowledged uncertainty. Uncertainty is the most powerful weapon of the antitransgenic movement. The elision of and escalation from uncertainty to anxiety meets little cognitive resistance. Fearing the unknown is not only a first response, but a rational response. There cannot be, for example, conclusive evidence that transgene flow will not cause ecological disruption somewhere, sometime. Real science is inevitably, often radically, incomplete. High anxiety with low information 
is the condition most likely to generate the powerful effects of symbolic politics (Edelman, 1964: 91-92, passim). Where science is uncertain, opponents of transgenics have had ready answers.

There is thus introduced a deep indeterminacy into biopolitics: science is a powerful cognitive filter that stands between structure and interest. Science continually presents new challenges to the way interests are understood by citizens and political classes that control states; the sea change in redefinitions of interests introduced by the atmospheric science of ozone holes and climate change is archetypal. Counter-intuitive links between refrigerator gases and skin cancer were not on the agenda of citizens in pre-Montreal Protocol days; there was a time when climate change was on no one's political horizon. Transgenic organisms represent a particularly compelling instance of these dynamics. Ecosystem health, biodiversity, allergenicity, gene flow - all are sufficiently removed from ordinary conceptual and practical knowledge of most people that reliance on experts, congealed knowledge, or persuasive framing, becomes inevitable. Effects take a long time to become apparent; causality in over-determined chains of dynamics is difficult to parse. And the science keeps changing. Interests are knowledge-dependent, but the knowledge is constantly in flux at the margins, and contested.

It is not surprising that opponents of biotechnology are suspicious of the science. Because science is expensive, what will be found out depends in part on who funds what research, and how much of whatever is found out is suppressed or ignored. Allocative decisions within big science will be driven by markets and politics, not free-floating curiosity or epistemic necessity. In court, each side has its scientists. There are potentially high stakes in small findings - hence restrictions on international field-work for fear of biopiracy. The value of these new commodifications of nature is dependent on social acceptability of the enabling science that certifies safety of products and procedures. Pharmaceuticals have created a spectacle of politicised science for mass publics uninterested in science, but deeply interested in health. NGOs in India demanded field-trial data on $B t$ cotton vociferously while simultaneously telling anyone who asked that no one would believe the results if released - data were produced by a state that was promoting biotechnology, by scientists whose careers depended on the results and by commercial interests with profits at stake. ${ }^{30}$ It is equally true that many critics would lose livelihoods if 'GMO' controversies died out.

The genomics revolution created possibilities for conversion of nature to property unimaginable a generation ago (Tanksley and McCouch, 1997). There is a profound question of social justice in allocating returns from property in nature: whether or how those who have forgone benefits from destruction of nature by leading impoverished but low-impact lives might benefit from new knowledge. This potential seemed to alter the biopolitics of conservation, giving nature itself tangible value. So long as biodiversity is valued only in normative terms, as a desirable thing, its political base is everywhere fragile. But valuable genetic information may depend on actually existing biodiversity. Biotechnology potentially valorises, perhaps remunerates, both biodiversity and local knowledge (Gupta, 1998; Weiss and Eisner, 1998). Yesterday's pest could harbour tomorrow's miracle gene; who is opposed to curing cancer? In the normative spectrum from 'biopartnerships', to 'bioprospecting' to 'biopiracy', there is a common assumption that variable relationships between value 
and new forms of property are worth contesting (Svarstad and Dhillion, 2000). Through this knowledge-based revaluation of nature, potential monetary incentives are injected into the political struggle over micro-nature. For some years, the Environment Minister had something to say to the Commerce Minister when opportunity costs of conservation were questioned. ${ }^{31}$ Bioprospecting largely failed to materialise, but the very potential left behind opposition to biopiracy. When the BBC characterised the Indian firm Navbharat's appropriation of Monsanto's Bt cotton gene as 'biopiracy', the rhetorical tables were turned; the assumption that genetic flow can move only from South to North is clearly problematic.

Anti-transgenic ideologies have a tactical political advantage in biopolitics, derived from core characteristics of science-as-method - sceptical agnosticism, tentative conclusions, replicability, validation in epistemic communities - commitments at odds with the simple messages and certainty privileged by politics. Junk science forgoes these complications in favour of reductionist explanations that evoke anxiety in spheres of low information or cognitive complexity: 'the terminator will terminate biodiversity' was ringing through rallies even as farmers saved, propagated and replanted the 'terminator' seeds in India. A claim in real time that UN food shipments to Africa are 'poison' will elicit a precautionary response; it is quite a different matter to assess the probabilities that some novel proteins may prove allergenic to some people at some time. As science is inevitably a work in progress, and therefore incomplete, uncertain if honest - mis-recognition of interests through obfuscating ideologies renders real science politically vulnerable in biopolitics.

\section{Development Frontiers}

Despite Michael Lipton's caution that biotechnology's 'hype-line' often over-runs the 'pipeline', there is a great deal at the frontier. Thies and Devare discuss how rDNA technology is being used to create crops resistant to abiotic stresses such as drought, soil acidity, and salinity. Advances in resistance to abiotic pressures could stabilise and increase yields of crops grown in marginal, low-productivity areas in which the poor are often trapped. Increased storage stability and delayed ripening would disproportionately benefit those with little market holding power or resources to invest in storage and transport facilities.

Because of the seemingly limitless scope of genetic engineering, development discourse has placed too much emphasis on the seeds themselves: whether 'miracle seeds' or 'suicide seeds'. Alleviation of the life-limiting conditions of poverty cannot rely on technical change. The primary causes of poverty, and therefore solutions, lie in much larger structural forces and policy choices. Seeds cannot carry too much of the load when so much is biased against the poor.

Development policy hinges on alternatives: compared to what? The emerging consensus among development professionals is that more public sector funds should go into biotechnology, in part to mitigate poverty. But what returns at the margin would justify more international funding of transgenics? At the cost of what other projects? It is easy to argue that biofortification research is more likely to aid the poor than any number of amorphous and trendy sinkholes for monies that satisfy cyclical imperatives of funders and fundees. But what of research on invasive species 
and ecological decline, water conservation - or agroecology? The frontier issue is opportunity costs at the margin: the best use of the additional dollar.

The first ethical dictum of development policy is to do no harm. Yet there is no consensual metric to determine how much caution is warranted, how much is too costly. Consider the problem of scale. Agro-ecologies vary from district to district in India, even from village to village, but are not fully mapped. Does a biosafety regime require testing across all ecological variations, or is rough comparability enough? What is an adequate sample? The Nuffield Council on Bioethics recommends sharing methods and data among countries that have similar agroecologies (2004: 73-75). This recommendation begs the question: how similar? Rajasthan is something like Texas, sharing acacias and low rainfall, but is quite different in other ways. Few would argue that Texas data are proxies for Rajasthan, but does one test district by district, village by village? For how long? If we knew what exactly in the ecology needed to be matched up, we would have powerful enough theory to do away with much testing. There is institutional uncertainty as well. Mechanisms for biosafety are almost certain to be at least partially ineffective: is the certainty of gene-use restriction technology - aka 'the terminator' - a more cost-effective answer to gene flow? A terminator that could ensure some biosafety desiderata could simultaneously render property claims of commercial firms much more enforceable than is currently the case. Under what conditions would societies accept terminator technology?

Equally unsettled are the comparative returns on different avenues of research. Compared to spraying toxins, $B t$ crops fare well in terms of biodiversity in the fields, human health and crop protection. But is the relevant comparison conventional agriculture - which many believe unsustainable - or alternatives from agroecological approaches? Norman Uphoff's contribution to this collection argues that research monies for improving genetic potential compete with superior pay-offs from agro-ecological research. Uphoff's data from multiple test sites across several continents on the system of rice intensification - itself subject to scientific controversy (Surridge, 2004) - suggest that there are novel ways to increase the percentage of genetic potential realised by plants in the field by improving management and technique. ${ }^{32}$ Is research in this field more productive at the margin than research designed to increase the nominal genetic potential of the plant itself? Uphoff's eco-agricultural techniques for rice are certainly compatible with rice that makes beta carotene in its grain, not just its leaves; the result would presumably be a double benefit for the poor: higher yields of more nutritious rice. Yet Golden Rice required an extraordinary feat of institutional cooperation to become viable and is yet to reach actual farmers (Kryder et al., 2000; Potrykus, 2004).

One could have Golden Rice with high or low yields; one could have high SRI yields with no pro-vitamin A in the endosperm, or only in the non-edible plant parts as with conventional rice. From an agro-ecosystem perspective, use of herbicidetolerant crops allows reduced and zero-till practices to work more effectively, reducing soil disturbance so as to retain more organic matter, improve soil structure, reduce soil compaction and improve soil water relations. In both cases, combination of agro-ecological advances with transgenics seems optimal, as some agro-ecologists recognise (McNeely and Scherr, 2003: 153). Bambawale et al. (2004) found that the best performance of participatory integrated pest management in their field study in 
India was with transgenic cotton - Bollgard 162. Devparna Roy's unpublished field investigation of organic farmers in India finds that some use $B t$ cotton - a transgenic crop very much contested nationally - with chemical-free cultivation techniques in accord with Gandhian values. ${ }^{33}$ This strategy of walking on two legs is the essence of Gordon Conway's (1997) 'doubly green revolution'.

There is but one problem with this sensible conclusion: the unresolved issue between Prometheus and Pandora. In the US, 'organic' is a standard that defines a rapidly expanding and advantageous market niche. 'Organic' officially excludes 'GMOs'. Yet the objectives of transgenic engineering and organic farmers in reducing soil erosion, synthetic chemical inputs and destruction of helpful insects are congruent. To the extent 'GMO-free' remains a meaningful market category, the threat of gene flow escalates in financial terms. It is precisely poorer farmers who have the lowest opportunity costs of labour and can engage in labour-intensive practices associated with organic agriculture. This market niche is thus of some importance to poor farmers, so long as rich consumers prefer organic produce and are willing to pay the premium. In this case, the externalities of transgenic crops through gene flow ('genetic pollution') are anti-poor, but only so long as the 'organic' label categorically rejects transgenic plants. This bright-line distinction between recombinant DNA and other methods of moving DNA around plants undermines an otherwise intuitive complementarity.

Whether or not genetic engineering constitutes a fundamental break in manipulation of plant genomes represented by thousands of years of breeding depends on a more basic cognitive divide impervious to data. This is a divide between what we might call an organismic view of nature and a molecularist view. From an organismic perspective, putting a fish gene into a tomato - a hoax used by opponents of genetic engineering, but not an inconceivable outcome - violates some threshold of the unnatural. For the pure molecularist, there are no fish genes or tomato genes, just variable organisations of bases in DNA, arranged in different networks: all life is composed of the same stuff. Different arrangements of this genetic variation are largely accidents of evolution. In the organismic view, species constitute the natural world; to disturb this order is 'playing god' (Herring, 2001). Political contestations of transgenic crops, like those in embryonic stem-cell research and cloning, depend more on theological and ontological dispositions than on science. Whether or not transgenic technology for the poor is in the public interest depends on how one conceptualises the public, how one couches the alternatives, the normative position one takes on uncertainty and risk, and the projections one makes from an inevitably incomplete science.

\section{Acknowledgements}

The editing services, patience and persistence of Kristen Ebert-Wagner made this collection possible; we all owe her a deep debt of gratitude.

\section{Notes}

1. Respectively, Dawkins (1997), McHughen (2000), Charles (2001), Paarlberg, (2001), Shiva et al. (2000). On the global divide, Winston (2002: 235-8), Pinstrup-Andersen and Schiøler (2000: 1-31). 
2. Ho and Ching (2003); e.g., The Union of Concerned Scientists in the US and the Independent Science Panel in the UK.

3. Defined as use of living organisms or their products for commercial purposes, biotechnology begins at least as early as written history in brewing beverages and making bread. Contemporary biotechnology is much broader than genetic engineering, including such techniques as tissue culture and markeraided selection.

4. Serageldin and Persley (2000). Claims of the unnatural nature of biotechnology reproduce - through references to Frankenfoods and even Frankenpants (made from Bt cotton) - the original Promethean connection established by the monster's creator: Mary Wollstonecraft Shelley subtitled her 1818 classic Frankenstein, 'The Modern Prometheus'.

5. The most notorious statement is perhaps that of Prince Charles, to the effect that scientists working on transgenic foods had strayed into 'realms that belong to God and God alone'. Though the Bush administration presses transgenics upon Europe and Africa, evangelicals in their coalition oppose genetic engineering on theological grounds.

6. Sharma (2004: 17-23) conjures the 'demon seed'; on the common attributions 'seeds of death' or 'suicide seeds', Herring (this issue).

7. Scientific American August 2004, 291(2): 8. The UNFAO warned that the 'war of rhetoric' might be more dangerous for small farmers than the transgenics themselves. Denying food to starving people to protect them from risk was almost certainly motivated by concern about European markets for agricultural products more than welfare of poor people.

8. Paarlberg (2001: 6-8 and Chapter 4); on developmental state theory, Woo-Cumings (1999).

9. Pinstrup-Andersen and Schiøler (2000: 31). The authors understand obvious problems in the Malthusian narrative, but there remains a wide-spread conception - echoing corporate public relations - that biotechnology means more food and more food means less poverty. To take but one (large) example, India is beset by staggering costs of managing 'surplus' food production, but the poor remain malnourished.

10. It is not known whether or not farmer suicides were abnormally frequent, nor what percentage were connected to economic distress (Karnataka, 2002), but the tragedy was attributed by some public intellectuals to transgenic seeds (Stone, 2001; Herring, 2005).

11. McHughen (2000: 63-66), Winston (2002: 11-34, et passim), Nuffield Council (2004: 22-5), Shelton (2004).

12. World Trade Organization regulations permit such technical barriers when 'information about health, hedonistic, or ethical attributes of agricultural products is either unknown or asymmetrically distributed between producers and consumers, and the transaction costs of obtaining this information are prohibitively high for consumers'. Roberts et al. (1999).

13. See his annual Global Status of Commercialized Transgenic Crops, ISAAA Briefs, Ithaca, NY. For 2004, James reports approximately 8.25 million farmers in 17 countries growing transgenic crops on about 81 million hectares; one-third of this area fell in low-income countries. The preponderance of area is in the US, Argentina, Brazil, Canada, and China.

14. Brazil was counted as zero in transgenic production until illegal movement of glyphosate-resistant soy seeds across international and internal borders assumed such proportions and raised so many political and juridical conflicts that the myth of 'GMO-free' could not be sustained; it is now a leading producer. Likewise, before 2002, India officially had no transgenic crops, but farmers were growing $B t$ cotton in several states. Paarlberg (2001: Chapter 4), Visvanathan and Parmar (2002), Herring (2005).

15. A 'development narrative' is a story both normative and causal, that simplifies complexity and through its simplifications suggests some course of action. Roe (1991), Dryzek (1997) for examples of useful application.

16. Genetic-use restriction technologies (GURT) were dubbed 'terminator technology' by RAFI, a Canadian NGO. It is a telling characteristic of contemporary global politics that a few people and a server could have launched so powerful a representation.

17. Curiously, the Nuffield Council Report (2004: 51-2) does not investigate this potential, despite its concern with the consequences of GURT.

18. On 18 November 2004, in hearings before the Senate Finance Committee in the United States, an FDA report was cited as estimating that 27,785 heart attacks and sudden cardiac deaths would have been avoided if patients had not used Vioxx (rofecoxib), an arthritis drug, from 1999 through 2003. Text relies on CSPAN telecast Senate committee hearings and reportage by the Washington Post and 
New York Times. The Editorial of the New England Journal of Medicine was posted to their web site, 8 December 2005.

19. James (2002). Evidence is discussed in this issue in contributions by Herring, Roy et al., Lipton, Pray and Naseem, Zilberman et al.

20. Ruifa $\mathrm{Hu}$ and Carl Pray, personal communication, find in their survey of about $400 \mathrm{Bt}$ farmers in China, self-labour constituted 96.5 per cent of the total labour used, hired labour only 1.7 per cent.

21. Winston (2002: 95) states that Johnson grass 'is a hybrid between cultivated and wild sorghum species'; the more common view holds the origin to be importation from the Mediterranean region. He notes that 'between one quarter and one third' of all domesticated crops are known to have transferred genes to wild relatives. See also Ammann et al. (2004).

22. On Indian farmers' cottage-industry hybridisation of transgenic cotton, Jayaraman (2004), Gupta and Chandak (2005), Herring (2007), Roy et al. (2007).

23. For early compendia of pro-poor potentialities, many of which seem born out in later empirical work, Qaim et al. (2000), Persley and Lantin (2000).

24. For results from a major project testing conceptual and empirical dimensions, see 'Democratizing biotechnology: genetically modified crops in developing countries,' Institute for Development Studies, University of Sussex, Brighton, UK, www.ids.ac.uk/biotech.

25. US Patent 5,723,765 granted 3 March 1998, held by Delta and Pine Land Company, in collaboration with the United States Department of Agriculture's Agricultural Research Service. Monsanto's attempt to purchase Delta and Pine Land failed, though this fact did not change the global protest focus on 'Monsanto's terminator'. Terminator technology was not commercialised, due in part to vigorous international protests and intervention of then-President of the Rockefeller Foundation, Gordon Conway (personal communication).

26. Pray and Naseem (2007) note that descriptions of many proprietary laboratory technologies have been published. Moreover, 'Some genes are in commercial use and can be obtained through reverse engineering, and some techniques have made their way to developing countries by way of unauthorised routes'. Patents either cannot be or have not been obtained in many - perhaps most low-income countries, and are unenforceable in others.

27. For example, debts at usurious rates to pesticide firms were a significant source of cotton-farmer financial crisis and widely publicised farmer suicides of 1998 in India. It is now clear that the CrylAc endotoxin in cotton substitutes for pesticides in a very cost effective way, more so when technology fees are avoided than when they are paid.

28. Conversations with seed producers in Gujarat, June 2005; they too do not know the precise acreage, as the farmers are producing $B t$ hybrids on their own farms and some still use transgenic F2 seeds. Data from Navbharat Seeds, progenitor of the first and most successful of the underground $B t$ lines, and parent to most, puts sales at 52.45 lakh packets of illegal Bt cotton for kharif 2005, enough seed cotton to plant 5.245 million acres, or roughly 25 per cent of India's cotton acreage (personal communication). Legal $B t$ sales are increasing rapidly as well. See Herring (this issue).

29. There was 'lively debate' on this question at a recent meeting of a scientific board of the US Environmental Protection Agency on this topic, with no resolution; the 'louder voices' supported more research to improve databases - not surprisingly. Personal communication from Dr Janice Thies, who attended.

30. My experience with $B t$ critics in various parts of India; see also Bharathan (2000). Mark Winston, a biologist, found that secrecy of the firms dealing in transgenics was a major source of distrust, but was experienced as an imperative by holders of inside information (2002: 55-7).

31. After the famous Merck-INBio deal's novelty wore off, this prospect decidedly dimmed. On the optimistic scenario, see Reid (1996), Gupta (1998), Weiss and Eisner (1998). For an economic explanation of failure, Simpson et al. (1996).

32. Also Uphoff (2002, 2003), Uphoff et al. (2002); for a broader view, McNeely and Scherr (2003).

33. They do this, Roy finds, of economic necessity: returns are higher and 'they have to feed their children'. Roy, personal communication; see also Roy et al. (2007).

\section{References}

Altieri, M. A. (2001) Genetic Engineering in Agriculture: The Myths, Environmental Risks and Alternatives, (Oakland, CA: Food First). 
Ammann, K., Jacot, Y. and Al Mazyad, P. R. (2004) Weediness in the light of new transgenic crops and their potential hybrids, Botanical Garden, University of Bern, Switzerland, accessed at: http:// www.botanischergarten.ch/Biotech-Biodiv/Report-Biodiv-Biotech12.pdf.

Bambawale, O. M., Singh, A., Sharma, O. P., Bhosle, B. B., Lavekar, R. C., Dhandhapani, A., Kanwar, V., Tanwar, R. K., Rathod, K. S., Patange, N. R. and Pawar, V. M. (2004) Performance of $B t$ cotton (MECH-162) under integrated pest management in farmers' participatory field trial in Nanded district, Central India, Current Science, 86(12), pp. 1628-33.

Bharathan, G. (2000) Bt-Cotton in India: anatomy of a controversy, Current Science, 79(8), pp. 1067-75.

Bouis, H. E. (2007) The potential of genetically modified food crops to improve human nutrition in developing countries, Journal of Development Studies, 43(1), pp. 79-96.

Center for Biological Informatics, US Geological Survey (n.d.) Invasive species information node, accessed at: http://invasivespecies.nbii.gov/

Charles, D. (2001) Lords of the Harvest: Biotech, Big Money, and the Future of Food, (Cambridge, MA: Perseus Publishing).

Cohen, J., Komen, J. and Zepeda, J. F. (2003) Innovation, regulation and capacity for bioengineered crops - sustaining a pro poor agenda?, paper presented at the Conference on Transgenics and the Poor, November 7-8, Cornell University, Ithaca, New York.

Conway, G. (1997) The Doubly Green Revolution: Food for All in the 21st Century (New York: Penguin Books).

Dawkins, K. (1997) Gene Wars: The Politics of Biotechnology (New York: Seven Stories Press).

Democratizing biotechnology: genetically modified crops in developing countries, Institute for Development Studies, University of Sussex, Brighton, UK, accessed at: www.ids.ac.uk/biotech.

Department of Biotechnology Ministry of Science and Technology, Government of India, (2001) Biotech News, 2(2).

Douglas, M. and Wildavsky, A. (1982) Risk and Culture (Berkeley: University of California Press).

Dryzek, J. S. (1997) The Politics of the Earth: Environmental Discourses (Cambridge: Oxford University Press).

Edelman, M. J. (1964) The Symbolic Uses of Politics (Urbana: University of Illinois Press).

Gonsalves, C., Lee, D. R. and Gonsalves, D. (2007) The adoption of genetically modified papaya in Hawaii and its implications for developing countries, Journal of Development Studies, 43(1), pp. 177-91.

Gupta, A. (1998) Rewarding local communities for conserving biodiversity: the case of the honey bee, in L. D. Guruswamy and J. A. McNeely (eds) Protection of Global Biodiversity: Converging Strategies, pp. 180-9 (Durham: Duke University Press).

Gupta, A. K. and Chandak, V. (2005) Agricultural biotechnology in India: ethics, business and politics, International Journal of Biotechnology, 7(1/3), pp. 212-7.

Herring, R. J. (1977) Land tenure and credit-capital tenure in contemporary India, in R. E. Frykenberg (ed.), Land Tenure and Peasant in South Asia (New Delhi: Orient Longman).

Herring, R. J. (2001, 3 Dec.) Promethean science, Pandora's Jug: conflicts around genetically engineered organisms in India, Mary Keating Das Lecture, Columbia University, New York. Transcribed and web-published.

Herring, R. J. (2003a) The political impossibility theorem of agrarian reform: path dependence and terms of inclusion, in P. P. Houtzager and M. Moore (eds) Changing Paths: The New Politics of Inclusion (Ann Arbor, MI: University of Michigan Press).

Herring, R. J. (2003b) Data as social product, in R. Kanbur (ed) Q-Squared: Combining Qualitative and Quantitative Methods in Poverty Appraisal (New Delhi: Permanent Black).

Herring, R. J. (2005) Miracle seeds, suicide seeds and the poor: GMOs, NGOs, farmers and the state, in R. Ray and M.F. Katzenstein (eds) Social Movements in India: Poverty, Power, and Politics, pp. 203-32 (Lanham, MD: Rowan and Littlefield).

Herring, R. J. (2007) Stealth seeds: bioproperty, biosafety, biopolitics, Journal of Development Studies, 43(1), pp. 130-57.

Herring, R. J. and Edwards, R. M. (1983) Guaranteeing employment to the rural poor: social functions and class interests in the employment guarantee scheme in Western India, World Development, 11(7), pp. 575-92.

Hilgartner, S. (2002) Acceptable intellectual property, Journal of Molecular Biology, 319, pp. 943-6.

Ho, M.-W. and Ching, L. L. (2003) The Case For A GM-Free Sustainable World, (London: Independent Science Panel). 
Horsch, R. B. and Fraley, R. T. (1998) Biotechnology can help reduce the loss of biodiversity, in L. D. Guruswamy and J. A. McNeely (eds) Protection of Global Biodiversity: Converging Strategies, (Durham: Duke University Press).

Huang, J., Pray, C. and Rozelle, S. (2002) Enhancing the crops to feed the poor, Nature, 418(6898), p. 678 .

James, C. (2002) Global review of transgenic crops: 2001 feature: Bt cotton, ISAAA Briefs No. 26, ISAAA, Ithaca, NY.

James, C. (2003) Preview: global status of commercialised transgenic crops: 2003, ISAAA Briefs No. 30 , ISAAA, Ithaca, NY.

Jayaraman, K. S. (2001) Illegal Bt cotton in India haunts regulators, Nature Biotechnology, 19(12), p. 1090.

Jayaraman, K. S. (2004) India produces homegrown GM cotton, Nature Biotechnology, 22(3), pp. $255-6$.

Jeyaratnam, J. (1990) Acute pesticide poisoning: a major global health problem, World Health Statistics Quarterly, 43, pp. 139-44.

Government of Karnataka (2002) Farmers' suicides in Karnataka: a scientific analysis, report of the Expert Committee for Study on Farmers' Suicides, Bangalore.

Kloppenburg, J., Jr. and Kleinman, D. L. (1987) Seed wars: common heritage, private property, and political strategy, Socialist Review, 95(September/October), pp. 7-41.

Kothari, S. and Chawla, M. (eds) (2002) U N DeePer in the Techno-Corporate Mire. Kalpavriksh, Lokayan et al. New Delhi.

Kryder, R. D., Kowalaski, S. P., and Krattiger, A. F. (2000) The intellectual and technical property components of Pro Vitamin-A Rice (Golden Rice ${ }^{\mathrm{TM}}$ ): a preliminary freedom-to-operate review, ISAAA Brief No. 20, ISAAA, Ithaca, NY, USA.

Liptak, A. (2003) Saving seeds subjects farmers to suits over patent, New York Times, 2 November, p. 1,18.

Lipton, M. (2007) Plant breeding and poverty: can transgenic seeds replicate the 'green revolution' as a source of grains for the poor?, Journal of Development Studies, 43(1), pp. 31-62.

Lybbert, T. J. (2002) Humanitarian use technology transfer: issues and approaches, Intellectual Property Strategy Today, 2, pp. 17-24. Revised version in International Journal of Food, Agriculture \& Environment, 1(2003), pp. 95-9.

Leissinger, K. M. (2000) Ethical challenges of agricultural biotechnology for developing countries, in G. J. Persley and M. M. Lantin (eds) Agricultural Biotechnology and the Poor (Washington, DC: Consultative Group on International Agricultural Research).

Lele, U. (2003) Biotechnology: opportunities and challenges for developing countries, American Journal of Agricultural Economics, 85, pp. 1119-25.

Madsen, S. T. (2001) The view from Vevey, Economic and Political Weekly, 29, pp. 3733-42.

McHughen, A. (2000) Pandora's Picnic Basket: The Potential and Hazards of Genetically Modified Foods (Oxford: Oxford University Press).

McNeely, J. A. and Scherr, S. J. (2003) Ecoagriculture: Strategies to Feed the World and Save Wild Biodiversity (Washington: Island Press).

Mead, P. S., Slutsker, L., Dietz, V., McCaig, L. F., Bresee, J. S., Shapiro, C., Griffin, P. M. and Tauxe, R. V. (2004) Food-related illness and death in the United States, Emerging Infectious Diseases [US Centers for Disease Control and Prevention], 5(5).

Moore, M. (2003) Arguing the politics of inclusion, in P. Houtzager and M. Moore (eds) Changing Paths: The New Politics of Inclusion, (Ann Arbor, MI: University of Michigan Press).

Moose, S. (2003) StarLink ${ }^{\mathrm{TM}}$ : fallout from a shooting biotech star. University of Illinois, accessed at: http://agronomyday.cropsci.uiuc.edu/2001/tours/Starlink/.

Munkvold, G. P., Hellmich, R. L. and Rice, L. G. (1999) Comparison of fumonisin concentrations in kernels of transgenic Bt maize hybrids and non-transgenic hybrids, Plant Disease, 83, pp. 130-8.

Nanda, M. (2003) Prophets Facing Backward: Postmodern Critiques of Science and Hindu Nationalism in India (New Brunswick, NJ: Rutgers University Press).

Nuffield Council on Bioethics (1999) Genetically Modified Crops: The Ethical and Social Issues (London: Nuffield Council on Bioethics).

Nuffield Council on Bioethics (2004) The Use of Genetically Modified Crops in Developing Countries (London: Nuffield Council on Bioethics).

Paarlberg, R. L. (2001) The Politics of Precaution: Genetically Modified Crops in Developing Countries (Baltimore, MD: Johns Hopkins University Press). 
Persley, G. J. and Lantin, M. M. (eds) (2000) Agricultural Biotechnology and the Poor (Washington, DC: Consultative Group on International Agricultural Research).

Pimentel, D., Tort, M., D’Anna, L. and Krawic, A. (1998) Ecology of increasing disease, Bioscience, 48(10), pp. 817-26.

Pinstrup-Andersen, P. and Schiøler, E. (2000) Seeds of Contention: World Hunger and the Global Controversy over GM Crops (Baltimore: Johns Hopkins University Press).

Potrykus, I. (2004) Experience from the humanitarian Golden Rice project: extreme precautionary regulation prevents use of green biotechnology in public projects, BioVision, Alexandria, 3-6 April.

Pray, C. E., Huang, J., Hu, R. and Rozelle, S. (2002) Five years of Bt cotton in China- the benefits continue, The Plant Journal, 31(4), pp. 423-30.

Pray, C. E. and Naseem, A. (2007) Supplying crop biotechnology to the poor: opportunities and constraints, Journal of Development Studies, 43(1), pp. 192-217.

Qaim, M. and Zilberman, D. (2003) Yield effects of genetically modified crops in developing countries, Science, 299(5608), pp. 900-2.

Qaim, M., Krattiger, A. F. and Von Braun, J. (eds) (2000) Agricultural Biotechnology in Developing Countries: Towards Optimizing the Benefits for the Poor (Boston: Kluwer Academic Publishers).

Reid, W. V. (1996) Gene co-ops and the biotrade: translating genetic resource rights into sustainable development, Journal of Ethno-Pharmacology, 51, pp. 75-92.

Roberts, D., Josling, T. E. and Orden, D. (1999) A framework for analyzing technical trade barriers in agricultural markets, USDA Economic Research Service, Technical Bulletin Number 1876, March.

Roe, E. (1991) Development narratives, or making the best of blueprint development, World Development 19(4), pp. 287-300.

Rogers, E. M. (1995) Diffusion of Innovations (New York: Free Press).

Roy, D., Herring, R. J. and Geister, C. C. (2007) Naturalising transgenics: official seeds, loose seeds and risk in the decision matrix of Gujarati cotton farmers, Journal of Development Studies, 43(1), pp. 158-76.

Scientific American (2004) Editorial, 291(2, August), p. 8.

Serageldin, I. and Persley, G. J. Consultative Group on International Agricultural Research. (2000) Promethean Science: Agricultural Biotechnology, the Environment, and the Poor (Washington, DC: Secretariat Consultative Group on International Agricultural Research).

Scott, J. C. (1998) Seeing Like a State (New Haven: Yale University Press).

Sharma, D. (2004) GM Food and Hunger: A View from the South (New Delhi: Forum for Biotechnology and Food Security).

Shelton, A. M. (2004) Risks and benefits of agricultural biotechnology, in F. E. Ahmed (ed) Testing of Genetically Modified Organisms in Foods, pp. 1-53 (Binghamton, NY: Haworth Press).

Shiva, V. (2000) Stolen Harvest: The Hijacking of the Global Food Supply (Cambridge, MA: South End Press).

Shiva, V. (2001) Patents: Myths and Reality (Delhi: Penguin).

Shiva, V., Emani, A. and Jafri, A.H. (1999) Globalization and threat to seed security: case of transgenic cotton trials in India, Economic and Political Weekly, March, 6-12, 13-19.

Shiva, V., Jafri, A. H., Emani, A. and Pande, M. (2000) Seeds of Suicide: The Ecological and Human Costs of Globalisation of Agriculture (New Delhi: Research Foundation for Science Technology and Ecology).

Surridge, C. (2004) Feast or famine?, Nature, 428, pp. 360-1.

Svarstad, H. and Dhillion, S. S. (eds) (2000) Responding to Bioprospecting (Oslo: Spartacus Forlag AS).

Simpson, R. D., Sedjo, R. A. and Reid, J. W. (1996) Valuing biodiversity for use in pharmaceutical research, Journal of Political Economy, 104(1), pp. 163-85.

Tanksley, S. D. and McCouch, S. R. (1997) Seed banks and molecular maps: unlocking genetic potential from the wild, Science, 277(5329), p. 1063.

Thies, J. E. and Devare, M. H. (2007) An ecological assessment of transgenic crops, Journal of Development Studies, 43(1), pp. 97-129.

Stone, G. D. (2002) Biotechnology and suicide in India, Anthropology News, 43(5), p. 5.

United Nations Development Programme (2001) Human Development Report: Making Technologies Work for Human Development (New York: Oxford University Press).

UNFAO (2004) The State of Food and Agriculture 2003-2004: Agricultural Biotechnology: Meeting the Needs of the Poor (Rome: UNFAO). 
Uphoff, N. T. (ed) (2002) Agroecological Innovations: Increasing Food Production with Participatory Development (London: Earthscan Publications).

Uphoff, N., Fernandes, E. C. F., Yuan, L. P., Peng, J., Rafaralahy, S. and Rabenandrasana, J. (eds) (2002) The System of Rice Intensification: Proceedings of an International Conference, Sanya, China, April 1-4, 2002, Cornell International Institute for Food, Agriculture and Development, Ithaca, NY, accessed at: http://ciifad.cornell.edu/sri/.

Uphoff, N. (2003) Higher yields with fewer external inputs? The system of rice intensification and potential contributions to agricultural sustainability, International Journal of Agricultural Sustainability, 1(1), pp. 38-50.

Visvanathan, S. and Parmar, C. (2002) A biotechnology story: notes from India, Economic and Political Weekly, 6 July, pp. 2714-24.

Wambugu, F. (2000) The current and future situation of agricultural biotechnology in Africa, in M. Qaim, A. F. Krattiger and J. von Braun (eds) Agricultural Biotechnology in Developing Countries: Towards Optimizing the Benefits for the Poor (Boston: Kluwer Academic).

Weiss, C. and Eisner, T. (1998) Partnerships for value-added through bioprospecting, Technology In Society, 20, pp. 481-98.

Winston, M. (2002) Travels in Genetically Modified Zone (Cambridge, MA: Harvard University Press).

Woo-Cumings, M. (ed.) (1999) The Developmental State (Ithaca, NY: Cornell University Press).

World Health Organization (1999) Malnutrition worldwide, accessed at: http://www.who.int/nut/ malnutrition_worldwide.htm.

World Health Organization (2001) Nutrition/micronutrient deficiencies: combating vitamin A deficiency, accessed at: http://www.who.int/nut/vad.htm.

World Health Organization, The Food Safety Department (2005) Modern food biotechnology, human health and development: an evidence-based study, Geneva, June.

Zilberman, D., Ameden, H. and Qaim, M. (2007) The impact of agricultural biotechnology on yields, risks and biodiversity of low-income countries, Journal of Development Studies, 43(1), pp. 63-78. 